\title{
Students' Participation in and Contribution to Political and Social Change in Ethiopia
}

\author{
Abebaw Yirga Adamu and Randi Rønning Balsvik
}

\section{Introduction}

The future of any society depends on the next generation. Thus, providing individuals access to education and opportunities for participating in a country's development should be considered a necessity. In Ethiopia until the end of the 19th century, however, there was only traditional education, which was virtually controlled by the Orthodox Church. Modern education was introduced at the beginning of the 2oth century when Emperor Menelik established the first secular public school in 1907. Later, Emperor Haileselassie, who had recognized himself as the father of modern education in Ethiopia (Balsvik 1985; Wagaw 1990), expanded access to primary and secondary education. This created a demand for higher education to which the government responded by establishing the first higher education institution in the country in 1950, the University College of Addis Ababa (UCAA). In 1961, the UCAA was renamed Haileselassie I University (HSIU) and the Emperor became its first chancellor. At this time there was very little access to higher education but those who got the opportunity had actively participated in various national affairs.

Students' active participation in their countries' political, social and cultural issues can be considered a global phenomenon that emerged in the mid-188os (Zewde 2014). University students comprise one youth group that has been striving to bring political and social changes across post-colonial Africa, described in a study titled, Student protest - university and state in Africa 1960-1995, (Balsvik 1998). Demonstrating their contempt for the capitalist system as a strategy for development, and their leaders' abuse of power, " $[t]$ he students took upon themselves to be the conscience of the nation and the spokesmen of the downtrodden". In their self-image they were "more responsible for the future development of their countries than other groups" (Balsvik 1998, 316). This indicates university students' firm aspirations to be present in the process of social and political change.

The Ethiopian student movement became one of the strongest of its kind in Africa, and one of the vanguards of the international wave of student activism 
in the 196os (Balsvik 2012; Zewde 2014). Although the undemocratic rule of the Haileselassie government system was the main reason for its conception, there were also other contributory factors: Ethiopian student activism abroad, the global student movements, the anti-imperialist and pro-socialist movements in some Western countries, the presence of students from different African countries on Ethiopian government scholarships and the inculcation of Western ideologies through the curricula. The students that came to study in Ethiopia were politically mature and increased the political consciousness of Ethiopian university students (Zewde 2014), helping them in their attempts to express their opinions and unite the student population. Moreover, in Ethiopia all public higher education institutions are residential colleges (i.e., food, accommodation and health services are provided by universities) and this has given students an opportunity to create unity and solidarity through frequent intergroup contact.

This chapter examines student activism in Ethiopia, a country which, together with other Sub-Saharan African countries, has the lowest number of students in higher education in the world. While in 1995, $5^{8}$ per cent of the relevant age group was enrolled in tertiary education in high income countries, this was true of only three per cent on average in Sub-Saharan Africa. Women comprised only 15 to 20 per cent of the student population in higher education in Ethiopia in the 199os. The low number of women and their low standing in the Ethiopian culture explain why female students were far from numerous among the activists. But from the early 197os a few individual female students were willing to sacrifice, even their lives, for the cause for which the student movement fought (Balsvik 2007, 4-10).

Although there are studies which discuss the Ethiopian student movement in the 1960s and 1970s (see Balsvik 1985, 2007, 2009; Darch 1976; Kebede 2008; Tiruneh 1993; Zewde 2014), there is less scholarly discussion regarding university students' participation in, and contribution to, political and social change over time. Therefore, the following sections illuminate university students' participation in this field and advance the discussion of problems they faced during different regimes in Ethiopia. Moreover, comparative analysis across the regimes contributes to a better understanding of the issue of student activism in the country from social and political perspectives. It will be argued that students strongly influenced the political developments and social changes in Ethiopia until their unity was undermined by ethnic divisions. To better understand these issues, the next three sections of the chapter focus on students' participation in and contribution to political and social change during the preceding two and the current regimes - (1) the Haileselassie (Imperial) regime; (2) the Derg (Military) regime; and (3) the Federal Democratic Republic of Ethiopia (FDRE). 


\section{The Haileselassie (Imperial) Regime (1930-1974)}

The Haileselassie regime aimed at building a strong centralized state (Mengisteab 1997; Tronvoll 2000), designating homogenization as the nationbuilding strategy providing the best guarantee for state integration (Van der Beken 2008). In pursuance of this policy, the regime wanted to create a national culture, language and religion for all Ethiopians (Alemu and Tekleselassie 2006). As a result, Amharic was the only language used for media, courts, education and publication purposes. It was not legal to teach, publish or broadcast in languages other than Amharic and English (Boothe and Walker 1997; Markakis 1989). In practice, Amharic served as "the language of administration as well as the language and culture of integration" (Tronvoll 2000, 13).

Although Orthodox Christianity, Islam, Roman Catholicism and other religions co-existed, due to the policy of national integration the 1955 constitution declared Orthodox Christianity to be the religion of the empire, and the Emperor always professed the Ethiopian Orthodox Faith. Due to the Orthodox Church supremacy, "the concepts of the Ethiopian state and the Ethiopian Orthodox Church had been almost synonymous - both locally and internationally" (Friedman 1989, 249). Despite the assimilationist political system and state practice that denied equality to members of the diverse Ethiopian society, most university students and student activists preferred and advocated an Ethiopian nationalism which transcended all social identities and loyalties (Balsvik 2007; Tadesse 1993).

As any government does, the Haileselassie regime promised to bring development to the country. However, after three decades in power, it was not able to meet the basic needs and expectations of the majority of society. The regime's failure to address several social and political problems and the denial of equality created widespread dissatisfaction. However, it was difficult to challenge the futile political and administrative system as there was a lack of political consciousness among Ethiopians, most of whom were illiterate and working for landlords under a feudal system. There were also no civil society organizations or political parties to stand up for the rights of the larger society and voice its grievances. It was in such contexts that university students emerged as "the most outspoken and visibly the only consolidated opposition group" (Balsvik 1985, xiii) to challenge the system. The students considered themselves the "spokesmen and advocates of the 'suffering masses" (Balsvik 2009, 263). Although students were discontented with the political and social system of the monarchy prior to 1960, they made it public in the early 1960 s when they demonstrated in favour of the 1960 failed coup d'état while the emperor was on an official visit to Brazil. This was the beginning of many more anti-government student demonstrations. 
In the early 196os, the students used the campus poetry competition as a strategy to criticize the government system. They read poems on public stages which were attended by high officials of the government including the emperor. "Students can write on any topic under the sun, except on politics and religion" (University College Calls quoted in Zewde 2014, 73). However, the poetry competition was crippled because of strong censorship and punishment by the government. Later, the establishment of the University Students' Union of Addis Ababa and ideological support from Ethiopian students' unions in the USA and Europe provided new impetus to the student movement in the mid-196os. This helped them to raise important national issues in an organized way.

In 1964 the Ethiopian University Service was developed as a degree requirement in which students were expected to work one year (at the end of the third year) in the provinces, mostly as teachers (Balsvik 1985, 2012). This system also contributed to disseminating campus politics to a much wider population outside the university, raising consciousness among secondary school students and generating loyalty towards the informal leadership of university students (Balsvik 2012). One of the major social and political issues that students raised in the mid-196os was the abolishment of the feudal land tenure system which was considered a primary factor affecting agricultural productivity. Students advocated the need to implement land reform and marched on the streets of the capital chanting the famous slogan "Meret Learashu" which literally means "Land to the Tiller". They also demanded the government address different issues including corruption and rising prices (Turner 1991).

In spite of students' strong demands and continuous class boycotts and demonstrations, the imperial government did not significantly address social inequalities, the traditional political system, exploitation of peasants and corruption. The regime's reluctance to integrate the newly educated generation into the system incited rage and revolution among the students (Balsvik 2012). Discontented with the political, social and economic policies of the imperial regime, at the end of 196os, in addition to the land reform, students demanded a new political system and ideology that served social equity, advocating Marxism-Leninism as right and appropriate (Balsvik 1985; Tiruneh 1993). Some student activists also raised and discussed other important national issues regarding democratic rights which brought the matters of ethnicity and selfdetermination into the debate among the civilian left (Vaughan 2003). This eventually "gave secession a cloak of respectability that had not been there previously" (Tiruneh 1993, 30). The issue of ethnicity and secession was first publicly raised by Wallelign Mekonnen (1969) in his article titled, "On the 
questions of nationalities in Ethiopia", which was published in the students' union magazine called Struggle. As indicated in the excerpt below, Mekonnen, who was a student activist killed in 1972 when he and six other students attempted to hijack an Ethiopian airline, argued that Ethiopia is not one nation; rather it is made up of different nations and nationalities.

What are the Ethiopian people composed of? I stress on the word peoples because sociologically speaking at this stage Ethiopia is not really one nation. It is made up of a dozen nationalities with their own languages, ways of dressing, history, social organization and territorial entity. And what else is a nation? It is not made of a people with a particular tongue, particular ways of dressing, particular history, [and] particular social and economic organization? Then may I conclude that in Ethiopia there is the Oromo Nation, the Tigrai Nation, the Amhara Nation, the Gurage Nation, the Sidama Nation, the Wellamo [Wolayta] Nation, the Adere [Harari] Nation, and however much you may not like it the Somali Nation. This is the true picture of Ethiopia. There is of course the fake Ethiopian Nationalism advanced by the ruling class and unwillingly accepted and even propagated by innocent fellow travellers.

MEKONNEN 1969, 4

He also stated the need for a "genuine national-state" which is:

a state in which all nationalities participate equally in state affairs, it is a state where every nationality is given equal opportunity to preserve and develop its language, its music and its history. ... It is a state where no nation dominates another nation be it economically or culturally.

MEKONNEN 1969, 5

In order to achieve establishing a "genuine democratic and egalitarian state", he proposed different strategies including secessionist movement, which is the most controversial of all up until now.

There is nothing wrong with secessionism as such. For that matter secession is much better than nationally oppressive government. ...It is clear that we can achieve this goal [establishing a genuine democratic and egalitarian state] only through violence, through revolutionary armed struggle. But we must always guard ourselves against the pseudo-nationalist propaganda of the regime. The revolution can start anywhere. It can even 
be secessionist to begin with, as long as led by the progressive forcesthe peasants and the workers, and has the final aim the liberation of the Ethiopian.

MEKONNEN 1969, 7

The main objective of bringing up this issue here is to show how deeply students were engaged in the national socio-political issues of the country. It is not the aim of this paper to argue for or against the political implications of secession. However, it is necessary to mention that there are scholars who strongly assert that issues related to self-determination were not in the student movement agenda. The "discussion of the self-determination of nationalities within the student movement represented nothing more than the success of a subtle campaign of manipulation by Eritrean activists, designed to distort and subvert the radical movement in the furtherance of their own secessionist objectives" (Vaughan 2003, 130). Zewde (2014) also noted that the Eritrean insurgency played a significant role in the "origin and evolution" of the national question in the Ethiopian student movement.

At the end of the 1960 s and in the early 1970s, the student movement became the strongest force to challenge the imperial regime. Class boycotts and closure of the university were almost common phenomena (Darch 1976). The government did not like students' perseverance in fighting against what they believed was moving in the wrong direction. Repression and harsh punishment, rather than dialogue, became the usual government response to student expression (Balsvik 1985, 2012). In actions described as "upholding law and order", the government started taking severe measures including the killing of student representatives and activists by security forces. This did not stop the students; it rather united them and provided the impetus to hold anti-government demonstrations and demand change in the government. At the beginning of 1974, things started to get out of control. Different groups, including the trade unions, teachers, civil servants and taxi drivers, joined students in protesting against the imperial government.

The Military Coordinating Committee, which is commonly referred to as the Derg, was also formed and came to the forefront of the political stage for the first time. By that time, the imperial regime was a toothless lion which was unable to stop the wave of revolution first ignited by students some fifteen years earlier and followed by action by other civil and military groups in the early 1970s. Finally, after 45 years in power, in September 1974, the Haileselassie regime was overthrown by the Derg. Although there were nationalist, ethnonationalist and peasant opposition groups across the country that challenged 
the monarchy, the activities and contribution of students stand out most in overturning the ineffectual political and administrative system.

\section{The Derg (Military) Regime (1974-1991)}

Following the overthrow of the imperial regime, HSIU was renamed Addis Ababa University (AAU) in 1974. Although there were colleges in different parts of the country, for a population of about 41 million Ethiopia had only one university until 1985, the year Alemaya College of Agriculture became Alemaya (now called Haramaya) University. This is excluding Asmara University, which is now in Eritrea. When the Derg (also known as the Mengistu regime) assumed power in 1974, it is believed to have had no well-thought-out political plan, except a policy statement called Ethiopia Tikdem (Ethiopia First), which is "variously referred to by the Derg as its motto, slogan, philosophy, principle, ideology etc." (Tiruneh 1993, 66). Hence, it adopted Marxism-Leninism, which was the popular political ideology in the student movement at the time. The adoption of socialism as the principal political ideology had two main purposes - "to capture the imagination of the revolutionary youth ... and to compete with the civilian left for revolutionary leadership" (Gudina 2007, 7). This clearly shows the student contribution in bringing about political change which was believed to be important for the country's democratic development at the time.

Students were in favour of the revolution, but they opposed military rule which was against what they had been struggling for (Abate 1991). In pursuance of this stance, they adopted the resolution of the Confederation of Ethiopian Labour Unions which demanded the replacement of the military regime with a democratic people's government (Tiruneh 1993). They also reminded the military regime about "Land to the Tiller", the most popular slogan among students in their struggle against the imperial regime. On the other hand, in addition to constitutional declarations, to obtain legitimacy with the civilian left as well as the larger society the Derg had also taken on board different social development issues raised by the civilian left, notably in the student movement. As part of this strategy, the military regime came up with a development plan which is believed to have been instigated by administrators who had their origin in the student movement (Balsvik 2009). In order to bring about the planned development and changes in the country, the Derg created the Ediget Behibret Zemecha (Development through Cooperation Campaign) which is commonly referred to as Zemecha (campaign), which required students to take part as the main implementers. Students welcomed the development plan, but 
they initially refused to participate as their demands regarding the political administration and land issues had not yet been met.

When their initial refusal to participate failed to bring about change in the political administration, the students joined the campaign in January 1975, "half consenting enthusiastically and half feeling that they were being forced, both by the military and by circumstances" (Balsvik 2009, 262). However, it was believed that the students' determination was one of the factors that pressed the military government to issue the land proclamation that nationalized all rural land in March 1975, thought to be "one of the most radical land reform proclamations that any regime has ever issued" (Zewde quoted in Balsvik 2009, 261). This is another significant contribution by students to political and social change in the country. After the land reform proclamation, which mostly addressed the main historical criticism raised by ethnic groups (Gudina 2007), as part of building socialism in Ethiopia, and allegedly as a response to the demands of ethnic nationalism, the Derg came out with the declaration of the National Democratic Revolution (NDR) in 1976. The NDR declared that "the right to self-determination of all nationalities will be recognized and fully respected. No nationality will dominate another one since the history, culture, language and religion of each nationality will have equal recognition in accordance with the spirit of socialism" (Provisional Military Administrative Council 1976). The declarations of land reform and ethnic, religious, linguistic and cultural equality in the 1987 constitution seemed to be positive responses to the many inequalities perpetuated under the previous regimes. However, their implementation was far below social expectations.

At the beginning of 1975, the Derg announced the closure of AAU for an indefinite time because the participation of university students and teachers was required to implement the government's development plan. However, among some groups this was considered a systematic strategy to prevent students' unity of action which could have caused considerable pressure during the transition period (Balsvik 1994; Darch 1976; Haile-Selassie 1997; Turner 1991). According to Balsvik (2009, 261), "Approximately six thousand university students and teachers, and nearly fifty thousand secondary school students from all over the country, were sent to 437 places in the countryside." The campaign was generally intended to "teach and politicize the peasants" (Ahmed 2006, 298 ) and "to 'enlighten' the rural masses about development" (Tiruneh 1993, 102). In the course of the campaign, university students taught peasants about civil rights, land ownership and hygiene, created awareness of land redistribution, and participated in the formation of peasant associations, bringing literacy and building schools, clinics and latrines.

AAU was reopened in the 1976/1977 academic year. Students who returned from the campaign continued their opposition to the military regime, claiming 
that some of their fundamental questions had not been answered. Above all, they demanded the formation of a people's government. At the time, they were encouraged and influenced by the Ethiopian People's Revolutionary Party (EPRP), which was established during Haileselassie's regime by veterans of the student movement abroad, and became one of the main opposition political groups. The Derg understood the potential impacts of the continuing students' radical movement and it started taking measures such as banning the students' union and its publication, which was the main medium they used to express their opinions and standpoints. When student opposition and that from opposition political groups intensified, the military regime took severer measures still, including the Key Shibr (Red Terror) in which thousands of real and imagined opponents of the regime were killed, with youth comprising the main victims. Terrified by the situation, numerous students fled the country between 1976 and 1978, joining ethnicity-based armed liberation movements, and most of the others who continued their studies refrained from actively involving themselves in the country's politics and nation-building process. It can be argued that, "[f]or the student movement, the 1980 s were a time of both political hibernation and modest recovery from the repression of the second half of the 1970 ... students had become by this time politically impotent" (Ahmed 2006, 299).

The other contribution by students to social development during the Derg regime was their active participation in the resettlement and villagization programs which were part of the government's ten year development plan. Villagization and resettlement are two different but related programs (Steingraber 1987). The official objective of the villagization program was to promote rational land use, conserve resources and provide better social services (e.g. education and health), and the main objective of the resettlement program was to solve problems related to drought and famine (Abate 1991; Wubneh 1991). In the resettlement and villagization programs, rural peoples who were scattered across the country were clustered into villages, and people from the draught stricken north were moved to the south and southwest part of the country. The government planned to relocate 30 million people (two-thirds of the population) over about a decade; it is believed that by the end of 1989 , about 13 million rural habitants had been relocated in thousands of new villages established in 12 provinces (Wubneh 1991). These programs were considered "one of the largest mass movements of people anywhere in the world" (Steingraber 1987). In 1985, all higher education institutions were closed for two months as students and teachers went to assist in the programs. After this time, students' participation in political and social affairs stagnated until the military regime was overthrown in 1991 by the coalition of the ethno-nationalist movement mainly led by the Tigray People Liberation Front (TPLF). 


\section{The Federal Democratic Republic of Ethiopia (1991-present)}

In the years 1999-2005, eight new universities were established by merging and/or upgrading existing colleges and institutes. Although this resulted in an increase in student intake capacity, it was not able to respond to the rapidly expanding educational needs of the society or enhance economic growth, democracy and good governance in the country (Yizengaw 2003). Thus, in 2003, the government began the greatest expansion in the history of Ethiopian higher education. As a result, 21 universities were opened in less than a decade. In order to maintain continuity, however, this study mainly focuses on AAU students who, compared with students in other public universities, have most often tended to raise political and national issues, even since the current government came to power.

In 1995, following the transitional period (1991-1994), the FDRE was formed by the Ethiopian People's Revolutionary Democratic Front (EPRDF) which comprises four major ethnic political parties: the Amhara National Democratic Movement (ANDM), the Oromo People's Democratic Organization (OPDO), the Southern Ethiopia People's Democratic Movement (SEPDM), the TPLF and many other allied ethnicity-based political parties. The ruling political organization of the FDRE is dominated and led by the TPLF (Mehretu 2012; Parker and Woldegiorgis 2003; Van der Beken 2012; Woldeyohannes 2012).

By understanding Ethiopia as an ethnically diverse country with a political history of ethno-linguistic domination (Zewde 2004), the EPRDF-led government introduced an ethnicity-based federal system that, it was believed, would accommodate diversity and give dignity to all Ethiopians, irrespective of ethnic origin. Consequently, ethnicity became the ideological basis of the EPRDF government's political organization and administration (Abbink 1997; Parker and Woldegiorgis 2003; Smis 2008). As a result of the federal system, Ethiopia has become a federal polity with nine ethnicity-based regional states and two chartered cities that constitute the federation. According to the state policy, unity and Ethiopian national identity is based on the recognition of, and respect for, diversity (Van der Beken 2008; 2012), and ethnic federalism is "understood primarily as a mechanism of conflict resolution" (Vaughan 2003, 36).

University students' self-motivated participation in national political affairs continued soon after the EPRDF and other political organizations, including the Oromo Liberation Front (OLF), agreed to establish a transitional government which would engineer a new constitution and election. OLF was one of the rebellious groups that helped to overthrow the Derg regime and establish the Transitional Government of Ethiopia. In 1992, OLF withdrew from the government, and in 2011 the government of Ethiopia declared OLF one of the five 
terrorist entities (Adamu 2014). Contrary to what some student activists had proposed and advocated at the end of 196os, in 1993, AAU students demonstrated in protest against a planned referendum on Eritrean independence. The immediate response from the transitional government to this opposition was to order security forces to open fire on students demonstrating on the streets of Addis Ababa. Some students were also arrested and the university was temporarily closed (Ahmed 2006). Eventually, in April 1993 Eritrea became an independent country.

The 1995 constitution affirms that state and religion are separate, and that there is no state religion. The constitution also declared that everyone has the right to freedom of religion, and that believers can establish institutions of religious education and administration in order to propagate and organize their religion. Unlike in many countries in Western Europe and North America, where religion may be one of the basic dimensions of a political party (Reynal-Querol 2002), in Ethiopia, the government prohibits the formation of political parties based on religion (United States Department of State 2011). With regard to language, all are declared equal, although Amharic has retained the status of the working language of the federal government. Regional states have been given the right to choose their own working language which is applicable within their own territories. Yet, although the constitution declared that all ethnic groups are equal, several studies indicate that politics in Ethiopia has been dominated by the EPRDF, which in turn is led and dominated by a numerical minority, the Tigre ethnic group (Habtu 2004; 2005; Tronvoll 2000; Záhoř́k 2011). It seems that political domination by one ethnic group has continued and, therefore, "as the two previous regimes were largely identified with the Amhara, so the present government is widely perceived to be Tigrean" (Mengisteab 2001, 24).

The constitution also gives every ethnic group the unconditional right to self-determination up to the point of secession. It is assumed that this right will result in unity in diversity, and the creation of an Ethiopian national identity based on respect for ethnic diversity (Van der Beken 2008). Issues related to ethnicity and self-determination, which is constitutionalized by the EPRDF-led government, were first raised by student activists at the end of 196os (Gudina 2003), notably in Mekonnen's (1969) article. Emphasizing this, Vaughan $(2003,129)$ states, "The EPRDF has repeatedly accentuated its debt to those elements of the Ethiopian student movement, who first elucidated notions of self-determination of nationalities within the Ethiopian empire state, and laid the ideological basis for political mobilization on the basis of 'nationality". She adds that "over thirty years later, [Mekonnen's article] reads like a blueprint of the ideological position advocated by the TPLF/EPRDF" 
(Vaughan 2003, 136). Regardless of its implications, this shows the influence of students' thoughts and views on their country's politics.

As it will be discussed later, despite the governments' various strategies to disunite students, they continued to demand their rights and, at times, respect for the peoples' voice. For example, in 2001, AAU students demonstrated for greater academic freedom, freedom of association and expression, and the removal of armed police stationed on the campus. At the time, the AAU students' union and the publication of its newspaper were banned (Human Rights Watch [HRW] 2003; Rowan 2001). In 2001 students boycotted classes and demonstrated inside their campus, demanding a response from the university about the reestablishment of their union and newspaper which they often used to criticize academic and administrative issues on campus as well as the political and administrative system of the government. Government security forces entered the campus and beat students holding the peaceful demonstration. Seeking solutions and a reduction in tension, students held a meeting with the minister of education who denounced the police intrusion as illegal and unauthorized. However, no substantial agreement was reached between students and the government so students boycotted classes and went on strike again (Ahmed 2006), joined by students in other universities and secondary schools in a show of solidarity. According to HRW $(2003,18)$, "government forces responded to the protests with extreme brutality, killing more than thirty people, wounding some four hundred, and arresting thousands. ... about 250 students fled to Kenya; others went to Djibouti or Sudan." AAU students who withdrew from their studies as a result of the closure of the university were readmitted one year after the campus strike (Ahmed 2006).

Students have not been much involved in the political process and democratic development of the country since this brutal measure was taken by the present regime, but at times they have been very active in echoing societal activities and problems. For instance, in the 2005 general election, opposition parties rejected provisional results because of alleged voting irregularities, among other reasons. Following the controversial result, there was unrest in most parts of the country. Three weeks after the election date, defying the government's ban against demonstrations which was effective during the election period, AAU students mounted the first public protest over the general election that resonated with opposition parties' complaints. Immediately, students in many other universities and secondary schools across the country protested the election result in solidarity with majority of Ethiopians. However, this failed to result in any change, and once again thousands of students were beaten and arrested by security forces. 
In May 2016 the government revealed its integrated master plan for the capital, Addis Ababa, to expand into Oromia Regional State. The Oromo people claimed that this did not have their consent, and that such a plan would lead to the eviction of Oromo farmers from their land. Although people from other ethnic groups felt the same way, it was only Oromo students from universities in Oromia Regional State who protested against it. This clearly demonstrates the insecurity of students in universities that are geographically located away from the concern at hand and the lack of solidarity among students from different ethnic backgrounds even when they share a concern. Perhaps this also shows the erosion of long existing elements of social cohesion underlying Ethiopian society. Following the demonstration by the university students many people in towns in Oromia protested against the government. Before it decided to halt its integrated master plan, the government crushed the demonstration by arresting and killing numerous people including students. For example, several students in Madawalabu University were killed and about twenty AAU students were arrested (Amnesty International 2016; British Broadcasting Corporation 2016; Counter Punch 2016; HRW 2016).

Nowadays, there are a number of important national issues that students need to discuss and contribute to addressing in different ways. These include but are not limited to academic freedom, the quality of education, the political system, human rights, land grabbing, forced resettlement, ethnic conflict, religious tension and the steep rise in prices which are increasing more than ever before. Although there are some political and social situations which seem to be worse than during the preceding regimes, no significant contributions are being made by students to alleviate these problems. This is not so much because students do not want to participate in issues of national importance; it is rather because the government has designed different strategies to make sure that potential influence by students is prevented. Some of the ruling party elites, including Meles Zenawi, the late prime minister and chairperson of the EPRDF, were members of the strong and united student movement which protested against the imperial regime and later interrupted their studies to fight against the military regime. Clearly the current government is well aware of the potential influence of students in Ethiopian political and social change and wishes to avoid this when it comes to its own administration. That is why, from the very beginning of its administration, it has worked to create more dividing than uniting factors, and has taken such serious preventive measures. This has alienated students from participating and contributing to political and social change.

One of the main elements that have distanced students from being active in national affairs seems to be the ethnicity-based political and administrative 
system. Since its introduction, it is becoming more and more evident that many people's first allegiance is to their ethnic group, and "their country is a poor second" (Milkias 2011, 58); university students are no exception. This contradicts the ethnic and national sentiments of university students in Ethiopia in the late $1960 \mathrm{os}$. At that time students had a strong national identity and less ethnic and regional affiliation (Balsvik 2007; Young 1997). Studies and reports also indicate that the ethnicity-based federal system increased differences among ethnic groups in Ethiopia (International Crisis Group 2009), and encouraged division along ethnic lines (Engedayehu 1993) at the cost of national unity. This has been facilitated through, and emphasized by, the mass media and the ruling and opposition political parties' political indoctrination which, combined, have eroded students' unity and national sentiment.

The government has also weakened students' participation in national affairs by various strategies, one of which is making sure that a strong students' union like that of the preceding regimes does not emerge. In the 196os, Ethiopia had one of the strongest students' unions on the continent but now Ethiopian students are not represented at all in the All Africa Students' Union, which aims "to be fully involved in the peoples' struggles against all forms of domination, exploitation, discrimination, for peace, democracy and socio-economic development" (All-Africa Students Union). This is because there is no strong national student union in the country. Previous studies indicate that to continue in power, "it was considered important for the government to prevent the formation of united independent student unions across ethnic boundaries" (Balsvik 2007, 181). Moreover, amplifying historical grievances as part of the divide and rule strategy has created hatred and animosity among students from different ethnic backgrounds. Students who talk about national unity have been heavily criticized and considered anti-federalists and advocates of a unitary state. Another strategy is trivializing and labelling students' different national concerns as ethnic issues and as limited to a few students from certain ethnic groups. For example, in 1996, in the Amhara region, the government redistributed the land that it feels was unjustly acquired by people who had been associated with the previous military or imperial regime (UNDP 1997). In March 1997 AAU students demonstrated against the move (Ahmed 2006; Balsvik 2007), voicing their concern and opposition to the land redistribution system because they believed that the decision was unfair and politically motivated. But their concern was labelled as an issue only involving a few Amhara students who had benefited from the unjustly acquired land.

Yet another strategy used by the government to alienate students from participating in national affairs is to denounce questions raised by students as not coming from students, claiming that the students have been used as an 
instrument by other forces such as opposition parties, separatists and terrorist factions, even to the extent of associating students' questions regarding food quality with politics. Beside these strategies, expulsion from university, intimidation, arrest and killings are also factors that have distanced students from participating in important political and social issues. Because of the above mentioned causes, among other reasons, what seems to be more common among university students nowadays is division along ethnic lines, and ethnic conflict, than discussions and debates on important national political and social issues.

\section{Epilogue}

Students often want to be heard and to participate in their country's national affairs even when the government system ignores their contribution. In Ethiopia, university students' participation in important national issues started soon after the establishment of the first higher education institution in the country. The students during the Haileselassie regime created and enhanced political consciousness, and struggled for social equality and fair administration. It can be argued that they were the principal group of activists strongly challenging the imperial government's administrative and political system. The social policies and political ideologies which students proposed during the imperial regime were able to influence and give direction to some of the social policies and political ideologies of the following governments. The student movement was a significant force in the fall of the Haileselassie regime and in directing policies of the military regime.

During the military regime, students did not come up with new political and social ideologies and viewpoints as they had during the preceding regime, rather focusing on the realization of their previous political and social demands. Students' contributions to political and social change during the Derg regime came mainly through providing ideas and insights about political ideologies, and influencing the realization of social policies such as the land proclamation. They also contributed to social development by participating in a government-planned, multipurpose development campaign. Moreover, the 196os and 1970s student movement was a motivating factor and a symbol of solidarity and determination for several political and social groups in the country. However, their contribution gradually decreased because of a growing lack of freedom of expression and association, and the severe measures taken by the military regime.

As during the Derg regime, students have not come up with new ideas and opinions that would have positive impacts on the social and political 
development process of the EPRDF-led government. This may be somehow related to the presence of different civil society and political organizations that primarily work on such issues. Moreover, during the imperial and Derg regimes students had prioritized the struggle for a better life for the larger society over their own immediate and temporary needs such as better food and living conditions. Contrary to this, students in the EPRDF-led government system have been forced to focus on narrow issues that do not have national importance, and their views on some national issues have been silenced by the government's use of a range of different strategies. Although there are several reasons why students' participation in important national issues has been crippled, the ethnicity-based administrative and political system stands out as the parent of them all.

It can generally be argued that ever since higher education institutions opened in Ethiopia, university students have been the root cause of political and social change in the country, though, comparatively speaking, more during the imperial regime than the two that have followed. Their contribution has gradually decreased and, arguably, a time seems to have come when university students are no longer contributing to the political and social change and development of their country. Since the early 196os students have paid a heavy price for contributing to the nation-building process. Although they used peaceful strategies such as discussions and debates among themselves, and class boycotts, demonstrations, and publication and distribution of antigovernment texts, they were victimized in many ways (expulsion from their place of study, arrest, imprisonment, torture, and death). This has been the case during all the regimes, but brutality was highest, almost unprecedented in the world, during the military regime.

\section{References}

Abate, Yohannis. 1991. "The Society and Its Environment." In Ethiopia: A country study, edited by Thomas P. Ofcansky and LaVerle Berry, 88-155. Washington, DC: Federal Research Division.

Abbink, John. 1997. "Ethnicity and Constitutionalism in Contemporary Ethiopia." Journal of African Law 41 (2): 159-174.

Adamu, Abebaw Yirga. 2014. Ethnic and Religious Diversity in Higher Education in Ethiopia: The Case of Bahir Dar University. Tampere: University of Tampere Press.

Ahmed, Hussien. 2006. "Addis Ababa University: Fifty-Three Years on an Insider's View" Cahiers d'études africaines, 2(182): 291-312. 
Alemu, Daniel S., and Abebayehu A. Tekleselassie. 20o6. "Instructional Language Policy in Ethiopia: Motivated by Politics or the Educational Needs of Children?" Planning and Changing 37 (3/4): 151-168.

All-Africa Students Union. Objectives of All-Africa Student Union. http://www .aasuonline.org/ (accessed 21 October 2014).

Amnesty International. 2016. Ethiopia: Authorities must provide justice for scores of protestors killed, injured and arrested in Oromia. https://www.amnesty.nl/ nieuwsportaal/pers/ethiopia-authorities-must-provide-justice-scores-protesters -killed-injured-and-ar (accessed 15 May 2016).

Balsvik, Randi Rønning. 1985. Haile Sellassie's Students: The Intellectual and Social Background to Revolution, 1952-1977. Michigan: African Studies Center, Michigan State University.

Balsvik, Randi Rønning. 1994. "An Important Root of the Ethiopian Revolution: the Student Movement." In Ethiopia in Change: Peasantry, Nationalism and Democracy, edited by Abebe Zegeye and Siegfried Pausewang, 77-94, London-New York: British Academic Press.

Balsvik, Randi Rønning. 1998. "Student Protest: University and State in Africa 19601995." Forum for Development Studies 25 (2): 301-325.

Balsvik, Randi Rønning. 2007. The Quest for Expression: State and the University in Ethiopia under Three Regimes, 1952-2005. Addis Ababa: Addis Ababa University Press.

Balsvik, Randi Rønning. 2009. "Addis Ababa University in the Shadow of the Derg, 1974-1991." In Proceedings of the 16th International Conference of Ethiopian Studies, edited by Svein Ege, Harald Aspen, Birhanu Teferra and Shiferaw Bekele, 259-272. Trondheim: Norwegian University of Science and Technology.

Balsvik, Randi Rønning. 2012. "The Student Movement in Ethiopia and the Red Terror." Unpublished manuscript, University of Tromso.

Boothe, Ken, and Ronald Walker, W. 1997. "Mother Tongue Education in Ethiopia: From Policy to Implementation." Language Problems and Language Planning 21 (1): 1-19.

British Broadcasting Corporation. 2016. Ethiopian Forces 'Killed 4oo Oromo Protestors' http://www.bbc.com/news/world-africa-36546917 (Aaccessed 18 June 2016).

Counter Punch. 2016. Rise up People of Ethiopia. http://www.counterpunch.org/2014/ 05/23/rise-up-people-of-ethiopia/ (accessed 23 May 2016).

Darch, Colin. 1976. "The Ethiopian Student Movement in the Struggle Against Imperialism, 1960-1974." Paper presented at the 12th Annual Social Science Conference of the East African Universities, Dares Salaam, 20-22 December.

Engedayehu, Walle. 1993. "Ethiopia: Democracy and the Politics of Ethnicity." Africa Today 40 (2): 29-52.

Friedman, Galia. S. 1989. "Religion and the Marxist State in Ethiopia: The Case of the Ethiopian Jews." Religion, State and Society 17 (3): 247-256. 
Gudina, Merera. 2003. Ethiopia: Competing Ethnic Nationalism and the Quest for Democracy, 1966-20oo. Addis Ababa: Chamber Printing House.

Gudina, Merera. 2007. "The Problematic of Democratizing a Multi-cultural Society: The Ethiopian Experience." Paper presented at the Conference on Immigration, Minorities and Multiculturalism in Democracies, Montreal, 24-27 October.

Habtu, Alem. 2004. "Ethnic Pluralism as an Organizing Principle of the Ethiopian Federation." Dialectical Anthropology 28 (2): 91-103.

Habtu, Alem. 2005. "Multiethnic Federalism in Ethiopia: A Study of the Secession Clause in the Constitution." Publius 35 (2): 313-358.

Haile-Selassie, Teferra. 1997. The Ethiopian Revolution 1974-1991, from a Monarchical Autocracy to a Military Oligarchy. London-New York: Kegan Paul International.

Human Rights Watch. 2003. Lessons in Repression: Violations of Academic Freedom in Ethiopia. Vol. 15, No. 2A. New York: Human Rights Watch.

Human Rights Watch. 2016. Such a Brutal Crackdown Killings and Arrests in Response to Ethiopia's Oromo Protests. New York: Human Rights Watch.

International Crisis Group. 2009. Ethiopia: Ethnic Federalism and Its Discontents. Crisis Group Africa Report, nos.153-154. Brussels: International Crisis Group.

Kebede, Messay. 2008. Radicalism and Cultural Dislocation in Ethiopia, 1960-1974. Rochester, NY: University of Rochester Press.

Markakis, John. 1989. "Nationalities and the State in Ethiopia." Third World Quarterly $11(4): 118-130$.

Mehretu, Assefa. 2012. "Ethnic Federalism and Its Potential to Dismember the Ethiopian State." Progress in Development Studies 12 (2/3): 113-133.

Mekonnen, Wallelign. (1969). "On the Question of Nationalities in Ethiopia". Struggle, November 17 .

Mengisteab, Kidane. 1997. "New Approaches to State Building in Africa: The Case of Ethiopia's Ethnic-Based Federalism." African Studies Review 40 (3): 111-132.

Mengisteab, Kidane. 2001. "Ethiopia's Ethnic-Based Federalism: 10 Years After". African Issues 29 (1/2): 20-25.

Milkias, Paulos. 2011. Ethiopia (Africa in Focus). Santa Barbara, CA: ABC-CLIO.

Parker, Ben, and Abraham Woldegiorgis. 2003. Ethiopia: The Background, the Issues, the People. 2nd ed. Oxford: Oxfam.

Provisional Military Administrative Council. 1976. National Democratic Revolution Program. Addis Ababa: Provisional Military Administrative Council.

Reynal-Querol, Marta. 2002. "Ethnicity, Political Systems, and Civil Wars". Journal of Conflict Resolution 46 (1): 29-54.

Rowan, David. 2001. "Ethiopia: Students killed in brutal police attack." World Socialist Website, 27 April. https://www.wsws.org/en/articles/2001/04/ethi-a27.html (accessed 10 January 2013). 
Smis, S. 2008. "Ethiopia and the Right to Secession in International and Comparative Law." In Federalism and the protection of human rights in Ethiopia, edited by Eva Brems and Christophe Van der Beken, 107-125. Zurich: Lit.

Steingraber, S. 1987. "Resettlement and Villagization: Tools of Militarization in S.W. Ethiopia." Cultural Survival Quarterly, 11(4).

Tadesse, Kiflu. 1993. The Generation: The History of the Ethiopian People's Revolutionary Party-Part I: From the Early Beginnings to 1975. Trenton, NJ: Red Sea Press.

Tiruneh, Andargachew. 1993. The Ethiopian Revolution 1974-1987: A Transformation from an Aristocratic to a Totalitarian Autocracy. Cambridge: Cambridge University Press.

Tronvoll, Kjetil. 2000. Ethiopia: A new Start? London: Minority Rights Group International.

Turner, John W. 1991. "Historical Setting." In Ethiopia: a country study, edited by Thomas P. Ofcansky and LaVerle Berry, 27-87. Washington, DC: Federal Research Division.

UNDP. 1997. Horn of Africa. The Monthly Review, 21 February - 28 April. http://www .africa.upenn.edu/eue_web/hoao497.htm (accessed 14 January 2013).

United States Department of State [USDS]. 2011. The international religious freedom report. Accessed March 25, 2013 http://www.state.gov/documents/ organization/192923.pdf (accessed 25 March 2013).

Van der Beken, Christophe. 2008. "Ethiopia: Constitutional Protection of Ethnic Minorities at the Regional Level." In Federalism and the protection of human rights in Ethiopia, edited by Eva Brems and Christophe Van der Beken, 126-16o. Zurich: Lit.

Van der Beken, Christophe. 2012. Unity in Diversity: Federalism as Mechanism to Accommodate Ethnic Diversity-The Case of Ethiopia. Zurich \& Berlin: Lit.

Vaughan, Sarah J. 2003. "Ethnicity and Power in Ethiopia." PhD diss., University of Edinburgh, Edinburgh.

Wagaw, Teshome G. 1990. The Development of Higher Education and Social Change: The Ethiopian Experience. Michigan: Michigan State University Press.

Woldeyohannes, Samuel. 2012. Ethiopia: Creating a Culture of Progress. Claremont, CA: Phanos Press.

Wubneh, Mulatu. 1991. "The Economy." In Ethiopia: A Country Study, edited by Thomas P. Ofcansky and LaVerle Berry, 156-212. Washington DC: Federal Research Division.

Yizengaw, Teshome. 2003. "Transformations in Higher Education: Experiences with Reform and Expansion in Ethiopian Higher Education System." Paper presented at a Regional Training Conference on Improving Tertiary Education in Sub-Saharan Africa: Things that Work, Accra, 23-25 September.

Young, John. 1997. Peasant Revolution in Ethiopia: The Tigray People's Liberation Front, 1975-1991. Cambridge: Cambridge University Press. 
Záhořík, Jan. 2011. Ethnicity and Nationalism in Ethiopia: Some Recent Reflections. The Annual of Language \& Politics and Politics of Identity, 5, 91-108.

Zewde, Bahru. 2004. What Did We Dream? What Did We Achieve? And Where Are We Heading? Africa Insight 34 (1): 6-13.

Zewde, Bahru. 2014. The Quest for Socialist Utopia: The Ethiopian Student Movement 1960-1974. New York and Addis Ababa: James Currey and Addis Ababa University Press. 